\title{
Peran Aktif Bimbingan dan Konseling dalam Peningkatan Kualitas Pendidikan Madrasah Aliyah
}

\author{
Eko Wahyu Haderani ${ }^{1}$, Nur Sofianto ${ }^{2}$ \\ Prodi Bimbingan Konseling Pendidikan Islam, Prodi Tadris Fisika, Universitas Islam Negeri \\ Antasari Banjarmasin ${ }^{1,2}$, Indonesia \\ haderani@uin-antasari.ac.id, ekowahyu@uin-antasari.ac.id
}

\begin{tabular}{|c|c|c|}
\hline $\begin{array}{l}\text { First received: } \\
12 \text { Maret } 2021\end{array}$ & $\begin{array}{c}\text { Revised: } \\
25 \text { Maret } 2021\end{array}$ & $\begin{array}{l}\text { Final Accepted: } \\
20 \text { April } 2021\end{array}$ \\
\hline
\end{tabular}

\begin{abstract}
The role of guidance and counseling in coaching individual students in solving problems, challenges and difficulties is a demand that must be given by the guidance and counseling program in madrasah. The implementation of counseling guidance at Madrasah Aliyah Negeri throughout Banjarmasin has not yet been implemented in accordance with the objectives and functions of counseling guidance. The application of guidance and counseling is still visible in the routine curriculum of guidance and counseling activities. So that many types of main activities in counseling have not been implemented optimally. This research method is a descriptive qualitative research on the role of guidance and counseling in public madrasah aliyah throughout Banjarmasin. This study provides a description of how the pattern of guidance and counseling in state madrasah aliyah throughout the city of Banjarmasin. The result of this research is that counseling guidance at state madrasah Aliyah throughout Banjarmasin has played an active and optimal role in carrying out preventive, curative or corrective functions and perseverative functions, which have positive implications for achieving optimal educational goals and improving the quality and quality of education in State Madarasah Aliyah throughout the city of Banjarmasin.
\end{abstract}

Keyword: Guidance and Counseling Roles, Madrasah

\begin{abstract}
Abstrak
Peran Bimbingan dan konseling dalam pembinaan siswa secara individual dalam menyelesaikan hambatan, tantangan dan kesulitan merupakan tuntutan yang harus diberikan oleh program bimbingan dan konseling di madrasah. Penerapan bimbingan konseling Madrasah Aliyah Negeri seKota Banjarmasin belum berjalan sesuai dengan tujuan maupun fungsi bimbingan konseling. Penerapan bimbingan dan konseling masih terlihat dalam rutinitas kurikulum kegiatan bimbingan dan konseling. Sehingga banyak jenis kegiatan-kegiatan pokok dalam bimbingan konseling yang belum dilaksanakan dengan optimal. Metode penelitian ini adalah penelitian deskriptif kualitatif tentang peran bimbingan dan konseling pada madrasah aliyah negeri se-Kota Banjarmasin. Penelitian ini memberikan deskripsi gambaran bagaimana pola pembinan bimbingan dan konseling pada madrasah aliyah negeri se-Kota Banjarmasin. Hasil dari dari penelitian ini adalah bimbingan konseling pada madrasah Aliyah negeri se-Kota Banjarmasin telah berperan aktif dan optimal dalam melakukan fungsi preventif, fungsi kuratif atau korektif dan fungsi perseveratif, yang berimplekasi positif tercapainya tujuan pendidikan secara optimal dan terjadinya peningkatan kualitas dan mutu pendidikan di Madarasah Aliyah Negeri se-Kota Banjarmasin.
\end{abstract}

Kata kunci: Peran Bimbingan dan Konseling, Madrasah

\section{PENDAHULUAN}

Bimbingan dan konseling dirancang dan diimplementasi kan agar para peserta didik barada dalam kondisi prima secara emosional dan sosial, terlepas dari kendala-kendala masalah pribadi dan sosia serta memiliki pribadi yang sehat. 
Sehingga bimbingan dan konseling mampu melihat diri dan lingkungannya secara objektif, merancang dan mengambil keputusan yang tepat, dan perkembangan optimal dapat tercapai (Bhakti dan Safitri, 2017). Bidang layanan kepada peserta didik ini adalah layanan untuk membantu mengoptimalkan sesuai dengan potensi yang dimiliki (Muslihati, 2019). Layanan diarahkan pada tiga sasaran yaitu pengembangan dan pemecahan masalah dalam aspek sosial dan pribadi, pendidikan dan pembelajaran, serta pengembangan karer (Nurhayati, 2018).

Dalam keseluruhan proses pendidikan, program bimbingan dan penyuluhan merupakan suatu keharusan yang tidak dapat dipisahkan dari proses pendidikan pada umumnya. Dengan melalui program pelayanan bimbingan dan penyuluhan yang baik, maka setiap peserta didik diharapkan mendapatkan kesempatan untuk mengembangkan setiap potensi dan kemampuan yang dimilikinya seoptimal mungkin (Mahdi, 2017). Bimbingan dan konseling bertujuan untuk membantu individu (siswa) agar memperoleh pencerahan diri (intelektual, emosional, sosial dan moral spiritual) sehingga mampu menyesuaikan diri secara dinamis dan konstruktif serta mampu mencapai kehidupan yang bermakna (produktif dan konstributif), baik bagi dirinya sendiri maupun orang lain atau masyarakat (Farihah, 2013). Di sisi lain adanya peran bimbingan dan konseling dalam dunia pendidikan juga sangat diperlukan karena diharapkan akan mampu membawa peserta didik sampai pada standar kemampuan profesional dan akademis, juga perkembangan diri yang sehat dan produktif (Ramlah, 2018).

Bimbingan konseling merupakan upaya memungkinkan peserta didik mengenal dan menerima diri sendiri serta mengenal dan menerima lingkunganya secara positif dan dinamis, serta mampu mengambil keputusan, mengarahkan dan mewujudkan diri sendiri secara efektif dan produktif sesuai dengan peranan yang diinginkan dimasa depan (Putra, 2015). Tujuan umum dari pelayanan bimbingan konseling adalah kebahagiaan hidup pribadi, kehidupan yang efektif dan produktif, kesanggupan hidup bersama orang lain, dan keserasian cita-cita siswa dengan kemampuan yang dimilikinya (Putra, 2015). Program bimbingan disekolah pada pokoknya memberikan bantuan kepada anak didik untuk bisa berpikir mengenai pemilihan dan penyesuaian yang penting dan yang akan dihadapi dalam berbagai tahap hidup dimana seseorang dapat membuat persiapan secukupnya (Mahdi, 2017). Bimbingan konseling terdapat beberapa fungsi yang terpusat untuk membantu membuat rencana masa datang dan terbatas kepada lingkungan pemilihan pekerjaan dan penyesuaian diri dengannya (Farihah, 2013). Hal itu juga diperjelas oleh pernyataan Ramlah (2018) bahwa fungsi bimbingan konseling kemudian meluas pada aspek yang lain termasuk pendidikan, pribadi dan social.

Urgensi bimbingan dan konseling dalam pendidikan merupakan suatu kegiatan bantuan dan tuntunan yang diberikan kepada individu pada umumnya dan siswa pada khususnya disekolah dalam rangka meningkatkan mutu pendidikan ( Lusiyana dan Rohman, 2018). Namun Penerapan bimbingan konseling dalam dunia pendidikan belum berjalan sesuai dengan tujuan maupun fungsi bimbingan konseling, hal ini dikarenakan banyak jenis kegiatan-kegiatan pokok dalam bimbingan konseling yang belum dilaksanakan dengan optimal (Putra, 2015). Hal ini juga didukung oleh pernyataan (Permana, 2020; Farihah, 2013) bahwa Guru bimbingan konseling seharusnya 
memiliki cara pandangan bahwa siswa yang berprilaku menyimpang adalah siswa yang tidak mampu berprilaku baik, oleh karena itu perlu mendapat bantuan dan pertolongan agar siswa mampu berprilaku baik bukan menekan dan memaksa mereka agar berprilaku sesuai kehendak guru/sekolah, apalagi menghindar dengan mengambali kan peserta didik yang bermasalah kepada orangtua nya. Sehingga fingsi guru bimbingan konseling menjadi rutinitas kurikulum bimbingan konseling.

Berdasarkan observasi
Madrasah Aliyah Negeri se-Kota
Banjarmasin telah melaksanakan fungsi
bimbingan dan konseling pada siswa
sesuai dengan pedoman pelaksanaan
bimbingan dan konseling pada kurikulum.
Tetapi di lapangan masih banyak peran bimbingan dan konseling yang belum optimal karena terjebak pada rutinitas kurikulum. Rutinitas kurikulum yang dialamai oleh guru bimbingan dan konseling yaitu terjebak pada bimbingan rutin pribadi seperti misalnya hanya mememuhi jurnal guru bimbingan konseling pada satu semester, kurangnya memberikan koseling dengan optimal agar siswa berperilaku baik dan mampu memberikan saran dalam melanjutkan bimbingan karier setelah lulus madrasah aliyah(Sulma Marfija; Saadah, 2018). Sehingga diperlukan kajian deskriptif kualitatif dalam melihat keseluruhan bimbingan konseling pada Madrasah Alyah Negeri se-Kota Banjarmasin. Sehingga mampu melihat secara deskriptif hasil dari pelaksanaan bimbingan konseling pada Madrasah Aliyah Negeri se-Kota Banjarmasin.

\section{METODE}

Penelitian ini adalah penelitian deskriptif kualitataif dimana data yang didapat digambarkan secara kualitatif. Menurut Sugiyono (2018) penelitian deskriptif kualitatif didasarkan pada data yang digali baik berupa observasi, wawancara dan dokumentasi setelah itu peneliti menggambarkan hasil penelitian tanpa memberikan generalisasi hasil penelitian. Penelitian deskriptif kualitatif pada artikel ini menggambarkan bagaimana pelaksanaan peran bimbingan konseling pada Madrasah Aliyah Negeri se-Kota Banjarmasin. Jumlah objek penelitian sebanyak 3 Madrasah Aliyah Negeri se-Kota Banjarmasin yaitu Madrasah Aliyah Negeri 1 Banjarmasin, Madrasah Aliyah Negeri 2 Banjarmasin dan Madrasah Aliyah Negeri 3 Banjarmasin.

\section{HASIL TEMUAN}

Pelaksanaan kegiatan layanan bimbingan konseling pada Madrasah Aliyah Negeri se-Kota Banjarmasin dilakukan sesuai dengan perencanaan yang telah dipersiapkan pada bidang bimbingan pribadi, sosial, belajar, karier, kehidupan keragaman dan kehidupan berkeluarga. Bimbingan dan konseling menempati bidang pelayanan pribadi dalam keseluruhan proses dan kegiatan pendidikan. Bimbingan konseling berusaha untuk menemukan pribadi secara individual dimaksudkan agar siswa dapat mengenal kekuatan dan kelemahan dirinya sendiri serta menerimanya secara positif dan dinamis sebagai modal pengembangan diri lebih lanjut. Bimbingan dan konseling juga dapat mengenali lingkungan dan merencanakan masa depan. Berikut deskiptif kualitatif bimbingan dan Konseling pada Madrasah Aliyah Negeri 1 Banjarmasin, Madrasah Aliyah Negeri 2 Banjarmasin dan Madrasah Aliyah Negeri 3 Banjarmasin. 
a. Madrasah Banjarmasin

Madrasah
Aliyah Negeri

\section{Aliyah}

1 Banjarmasin melaksanakan bimbingan dan konseling dalam rangka menangkal dan mencegah perilaku-perilaku yang tidak diharapkan. Bimbingan dan konseling juga mengembangkan potensi konseling serta memfasilitasi mereka secara sistematik dan terprogram untuk mencapai standar kompetensi kemandirian. Upaya ini merupakan wilayah garapan bimbingan dan konseling yang dilakukan oleh guru bimbingan dan konseling Madrasah Aliyah Negeri 1 Banjarmasin secara proaktif dan berbasis data tentang perkembangan konseli beserta berbagai faktor yang mempengaruhinya.

Berikut salah satu bimbingan dokumentasi kegiatan konseling pribadi.

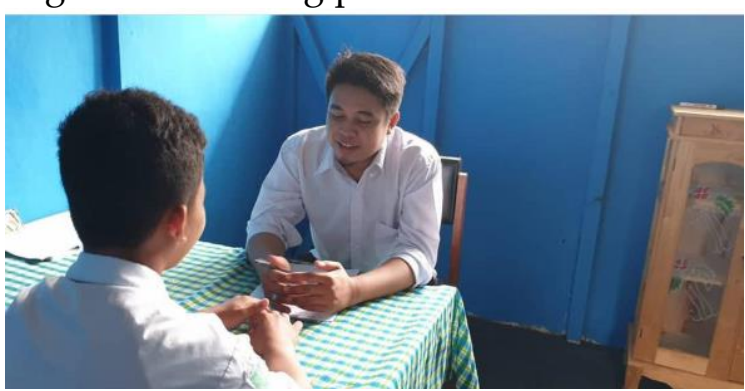

Gambar 1. Kegiatan Bimbingan Konseling Pribadi pada Madrsah Aliyah Negeri 1 Banjarmasin.

Kegiatan konseling pribadi dilaksanakan terhadap anak-anak yang memiliki masalah dalam kehidupan seharihari dan berpegaruh kepada kegiatan di sekolah (Legowo, 2017). Sehingga guru bimbingan konseling pada Madrsah Aliyah Negeri 1 Banjarmasin memberikan konseling secara pribadi kepada anak-anak yang memiliki masalah. Layanan konseling ini juga dapat diberikan melelui aktvitas media komunikasi lain misalanya Whats Up, Instagram dan Facebook. Berdasarkan hasil observasi saat kegiatan layanan pribadi siswa merasa aman, rahasia dan masalahnya terselesaikan menjadi kepuasan tersendiri bagi siswa.

Berdasarkan data wawancara dengan guru bimbingan konseling bahwa setiap siswa yang memiliki masalah pribadi dapat meminta layanan baik secara chat maupuan secara langsung. Pemberian layanan ini adalah bentuk dari tanggung jawab guru bimbingan konseling. Bagi siswa yang memiliki kendala di rumah yatu mengkomunikasikan dengan orang tua guru bimbingan konseling juga membantu layanan bimbingan hingga di rumah.

Layanan bimbingan dan koseling pada Madrasah Aliyah Negeri 1 Banjarmasin juga memberikan layanan sosial. Siswa yang mengalami masalah dengan satu teman yang lainnya akan diselesaikan secara damai dan menemukan solusi yang mudah dalam penyelesainnya.

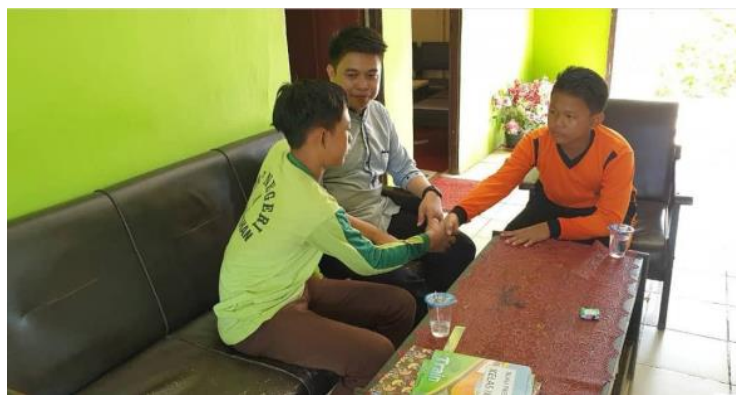

Gambar 2. Kegiatan Bimbingan Konseling Sosial pada Madrsah Aliyah Negeri 1 Banjarmasin.

Kegiatan bimbingan konseling sosial yang dilaksanakan oleh guru bimbingan konseling Madrasah Aliyah Negeri 1 Kota Banjarmasin mampu memberikan harapan bagi siswa untuk menyelesaikan masalahnya secara bersama dan damai(Muslihati, 2019). Hal ini juga didukung oleh pendapat Muhdi (2019) bahwa layanan bimbingan konseling sosial mampu menyelsaikan masalah secara damai dan tidak berkelanjutan.

Pada hasil wawancara terhadap guru bimbingan konseling bahwa layanan sosial ini diberikan apabila ada siswa yang bercerita memiliki masalah dengan temannya. Layanan konseling ini juga 
diberikan apabila ada teman yang memberikan laporan mengenai masalah yang dihadapi teman-temannya. Dalam pemberian layanan bimbingan konseling guru menghadirkan siswa yang mengalami masalah dan diberikan layanan untuk penyelesaian secara bersama-sama.

\section{b. Madrasah Aliyah Negeri 2 \\ Banjarmasin}

Guru bimbingan konseling pada Madrasah Aliyah Negeri 2 Banjarmasin melakasanakan bimbingan konseling secara individu dan sosial. Baik secara kalsikal di kelas atau dengan berkomunikasi dengan siswa yang memiliki masalah. Layanan bimbingan konseling pada Madrasah Aliyah Negeri 2 Banjarmasin juga memberikan bimbingan konseling bagi siswa yang mengalami kendala dalam pelajaran di kelas atau di lingkungan sekitar. Hal ini juga dinyatakan oleh Putra (2015) bahwa layanan bimbingan konseling memberikan layanan siswa yang mengalamai kesulitan dalam hal belajar baik di sekolah atau di rumah sehingga membantu siswa dalam belajar secara optimal.

Berdasarkan hasil observasi pada kegiatan layanan bimbingan konseling di Madrasah Aliyah Negeri 2 Banjarmasin siswa sering mengalami kendala dalam hal belajar karena Madrasah Aliyah Negeri 2 Banjarmasin adalah salah satu madrasah unggulan Kantor Wilayah Kementerian Agama Provinsi Kalimantan Selatan. Sehingga kesulitan siswa dalam belajar menjadi salah satu layanan bimbingan dan konseling. Sudah menjadi tugas guru bimbingan dan konseling yaitu membantu anak-anak atau siswa dalam memecahkan permasalahan yang sedang dihadapi (Mahdi, 2017). Berikut salah satu dokumentasi kegiatan layanan bimbingan konseling pada saat siswa mengalami kendala belajar.

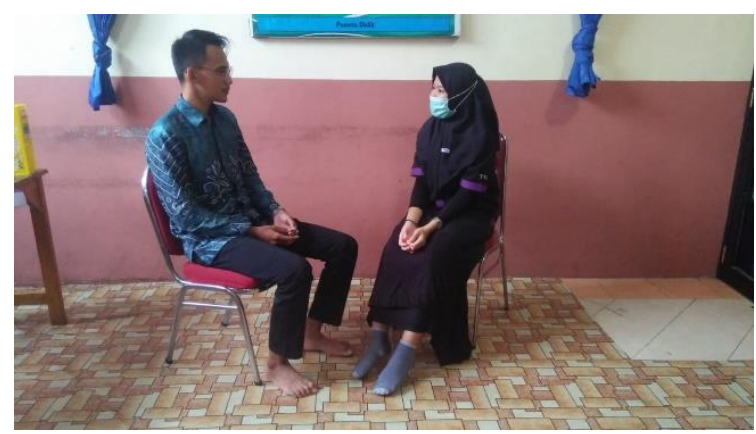

Gambar 3. Kegiatan Bimbingan Konseling Pribadi pada Madrasah Aliyah Negeri 2 Banjarmasin.

Siswa mengutarakan kesulitan dalam belajar salah satu pelajaran dan guru bimbingan konseling memberikan layanan pribadi tentang apa yang dihadapi saat belajar baik di kelas atau di rumah. Sehingga guru bimbingan konseling mampu memberi masukan bagaimana cara belajar yang baik dan dengan guru siapa saja bisa belajar dengan mudah dan belajar bersama(Nurhayati, 2018). Hal ini diungkapkan oleh Ramlah (2018) bahwa guru bimbingan konseling dapat membantu siswa keluar mengatasi permasalahan yang terjadi. Sehingga siswa lebih rajin lagi dalam belajar. Selain itu guru bimbingan konseling mampu menjembatani cara belajar siswa dengan kemampuan guru saat mengajar (Bhakti, 2015).

Berdasarkan hasil wawancara pada guru bimbingan konseling Madrasah Aliyah Negeri 2 Banjarmasin siswa mengalami kendala dalam hal belajar juga terjad salam kelompok yang sama. Sehingga layanan bimbingan konseling juga diberikan pada siswa yang mengalami kendala yang sama saat belajar. Berikut adalah salah satu dokumentasi kegiatan layanan bimbingan konseling siswa secara berkemlompok yang mengalami masalah pada saat belajar. 


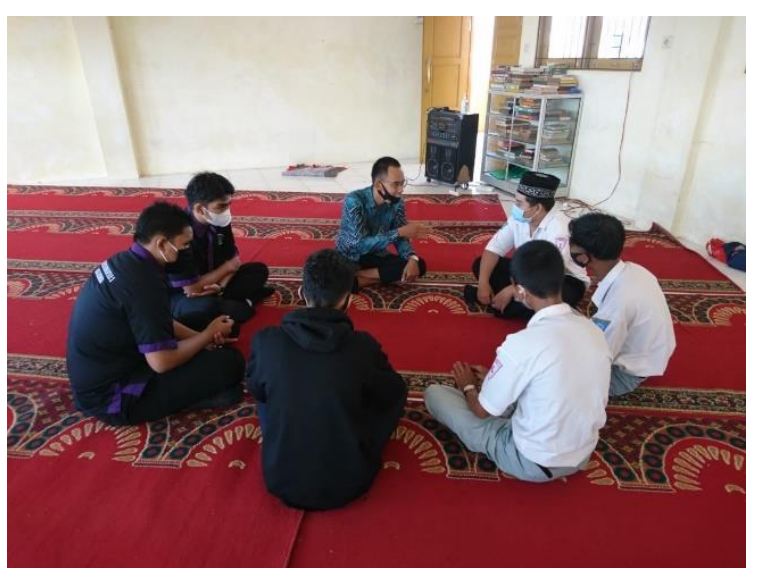

Gambar 4. Kegiatan Bimbingan Konseling Sosial pada Madrasah Aliyah Negeri 2 Banjarmasin.

Guru bimbingan konseling memberikan layanan sosial bersama siswa yang mengalami kendala saat belajar. Layanan ini juga mempertemukan pihak guru dan siswa sehingga terjadi komunikasi yang sesuai dengan arahan guru masing-masing bidang studi. Hal ini juga diungkapkan oleh Mahdi (2017) bahwa layanan bimbingan konseling dapat memberikan jembatan penyelesaian siswa yang mengalami masalah saat belajar dengan guru bidang studi.

\section{c. Madrasah Aliyah Negeri \\ Banjarmasin}

Layanan bimbingan konseling pada Madrasah Aliyah Negeri 3 Banjarmasin mengacu pada kurikulum 2013 tentang layanan bimbingan konseling. Guru bimbingan konseling memberikan layanan sesuai dengan kebutuhan siswa baik secara individu maupun sosial. Layanan bimbingan konseling pada Madrasah Aliyah Negeri 3 Banjarmasin juga mempertemukan siswa dengan mencari jalan keluarnya bersama dengan pihak yang berkepentingan. Berikut dokumentasi layanan bimbingan konseling dengan format konferensi.

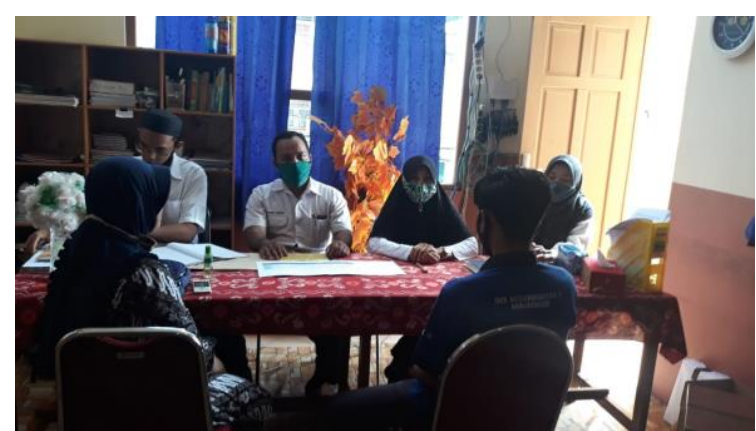

Gambar 5. Kegiatan Bimbingan Konseling Sosial pada Madrasah Aliyah Negeri 3 Banjarmasin.

Layanan bimbingan konseling secara konferensi diberikan dalam rangka mempertemukan pihak yang mengalami kendala sehingga masing-masing pihak yang mengalami masalah dapat menemukan jalan keluarnya. Hal ini juga diungkapkan oleh Ramlah (2018) bahwa dengan konseling secara konferensi setiap pihak yang mengalami kebuntuan atau kesulitan dalam kegiatan belajar dan kegiatan lainnya bisa mendapatkan jalan keluarnya.

Berdasarkan hasil wawancara pada guru bimbingan konseling Madrasah Aliyah Negeri 3 Banjarmasin siswa juga mendapatkan layanan bimbingan pribadi dan sosial hanya tergantung pada permintaan siswa. Apakah layanan yang diminta oleh siswa untuk memecahkan masalah. Berdasarkan hasil wawancara guru bimbingan konseling juga memberikan layanan siswa ke rumah sehingga dapat menjemput siswa yang kesulitan dalam belajar. Layanan bimbingan konseling pada Madrasah Aliyah Negeri 3 Banjarmasin juga mengantarkan siswa ke karier yang lebih baik setelah mereke 3 tahun di Madrasah Aliyah Negeri 3 Banjarmasin. 


\section{PEMBAHASAN}

Berdasarkan hasil temuan penelitian pada MA Negeri se-Kota Banjarmasin telah melaksanakan layanan orientasi, layanan informasi, layanan penyaluran atau penempatan, layanan bimbingan belajar, layanan konseling, pemberian nasehat dan layanan kosultasi. Layanan bimbingan konseling dapat mengaktualisasikan fungsi dan peran bimbingan dan konseling di madrasah. Hal ini juga dinyatakan oleh Muhdi (2019) bahwa fungsi layanan bimbingan konseling adalah memberikan layanan kepada siswa mulai dari layanan belajar hingga layanan konsultasi. Layanan bimbingan konseling telah dimplementasikan kepada fungsi pencegahan, perbaikan atau penyembuhan, serta pengembangan (Romlah, 2018). Hal ini akan memberikan pengaruh terhadap terciptanya iklim pendidikan madrasah yang kondusif dan peningkatan kualitas.

Berdasarkan hasil data temuan penelitian layanan bimbingan konseling pada Madrasah Aliyah Negeri se-Kota Banjarmasin telah melaksanakan layanan preventif. Layanan preventif dan fungsi penyesuaian dapat diberikan malalui layanan orientasi, layanan informasi, layanan kosultasi pada siswa (Muhdi, 2017) Dalam memberikan pencegahan dan penyesuaian siswa perlu diberi pemahaman tentang dirinya dan lingkungannya. Untuk itu layanan orientasi berusaha membantu siswa untuk mengenal dan memahami keadaan dan situasi yang ada pada lingkungan madrasah.
Siswa akan lebih mudah dalam mengikuti kegiatan-kegiatan madrasah guna mencapai keberhasilan belajarnya. Layanan bimbingan konseling secara preventif ini diharapkan dapat mencegah timbulnya permasalahan penyesuaian siswa dengan pola kehidupan sosial, kegiatan pembelajaran dan kegiatan ekstra kurikuler di madrasah yang berkaitan dengan keberhasilan siswa. Siswa akan diberikan layanan dalam kegiatankegiatan dalam orientasi yang bersifat positif dalam sikap saling menghargai, menghormati keanekaragaman dan persatuan, kedisplinan, hidup bersih dan sehat untuk mewujudkan siswa yang memiliki nilai integritas, etos kerja, dan semangat gotong royong.

Layanan bimbingan konselng pada Madrasah Aliyah Negeri se-Kota Banjarmasin berusaha membantu siswa untuk mengenal dan memahami keadaan dan situasi yang ada pada lingkungan madrasah. Layanan bimbingan konseling pada Madrasah Aliyah Negeri se-Kota Banjarmasin juga memberikan informasi dan pemahaman kepada individu-individu yang berkepentingan tentang berbagai hal yang diperlukan dalam menjalani suatu tugas atau kegiatan. Sehingga siswa meras terbantu dengan layanan bimbingan konseling (Bhakti, 2015). Siswa juga dibantu untuk menentukan arah suatu tujuan atau rencana yang dikehendaki.

Layanan bimbingan konseling pada Madrasah Aliyah Negeri se-Kota Banjarmasin Informasi sangat penting bagi setiap individu, lebih-lebih bagi individuindividu yang berkepentingan tentang berbagai hal yang diperlukan untuk menjalani suatu tugas atau kegiatan, atau untuk menentukan arah suatu tujuan atau rencana yang dikehendaki. Program bimbingan dan konseling membantu siswa dalam mengenali lingkungannya, terutama 
tentang kesempatan-kesempatan yang ada didalamnya. Salah satu contohnya adalah kegiatan konferensi pada gambar lima layanan bimbingan konseling yang dapat dimanfaatkan siswa dan semua pihak untuk menentukan pemecahan masalah dan mengambil kesempatan yang telah hilang selama ada kendala.

Layanan bimbingan dan konseling individu juga telah diterapkan pada masing-masing Madrasah Aliyah Negeri se-Kota Banjarmasin untuk membantu siswa memperoleh atau mengakses informasi. Sebagai usaha untuk membekali para siswa tentang berbagai macam pengetahuan supaya mereka mampu mengambil keputusan secara tepat dalam kehidupannya (Bhakti dan Safitri, 2017). Hal tersebut dapat menjadikan individu mandiri yaitu memahami dan menerima diri dan lingkungan secara positif, objektif dan dinamis, mampu mengambil keputusan, mampu mengarahkan diri sesuai dengan kebutuh- annya tersebut dan akhirnya dapat mengaktualisasikan dirinya.

Layanan bimbingan konseling pada Madrasah Aliyah Negeri se-Kota Bnajarmasin juga memberikan analisis tingkah laku mengdeskripsikan lingkungan sebagai stimulus atau kejadian. Kegiatan ini dapat kita lihat pada gambar empat bahwa stimulus diberikan ke siswa dalam rangka menyeelsaikan masalah yang berkaitan tentang kesulitan belajar secara bersama. Belajar sebagai suatu proses perubahan tingkah laku dimana reinforcement dan punishment menjadi stimulus untuk merangsang pembelajar dalam berperilaku (Arifin, 2003). Pengertian belajar ini memberikan langkah dalam pemberian bimbingan konseling untuk membuat siswa sadar akan belajar dan proses yang dilalui.
Berdasarkan hasil data penelitian tentang upaya preventif layanan bimbingan dan konseling pada Madrasah Aliyah Negeri se-Kota Banjarmasin dapat diketahui bahwa seluruh Madrasah Aliyah Negeri di Banjarmasin telah melaksanakan fungsi kuratif atau korektif malalui layanan konseling, pemberian nasehat, dan layanan kosultasi. Hal ini dapat kita lihat pada dokumentasi gambar satu hingga empat. Dalam melaksanakan fungsi kuratif atau korektif terhadap siswa bimbingan dan konseling Madrasah Aliyah Negeri se-Kota Banjarmasin telah diberikan layanan konseling dan pemberian nasehat. Karena kehidupan siswa tidak pernah terlepas dari masalah, baik secara jasmani maupun rohani. Hidup selayaknya timbangan, kita harus menyeimbangkan dua hal vital dalam kehidupan yaitu baik dan buruk.

Beberapa masalah sering menghantui setiap langkah dalam kehidupan seseorang siswa dan menuntut untuk segera dapat diatasi dengan cara yang tepat dan cepat. Namun seringkali cara yang digunakan untuk menyelesaikan berbagai permasalahan ini keliru dan tidak sedikit yang menyimpang dari norma-norma agama (Romlah, 2018). Layanan bimbingan konseling pada Madrasah Aliyah Negeri se-Kota Bnajarmasin mampu mengeksplor semua pilihan yang potensial untuk dapat menciptakan cara-cara baru yang inovatif. Hal ini juga didukung oleh pernyataan Bhakti (2015) bahwa dengan bimbingan konseling siswa mampu mengeksplor lebih banyak cara-cara untuk menyelesaikan masalah.

Layanan konseling pada Madrasah Aliyah Negeri se-Kota Banjarmasin juga membahas dan mengentaskan permasalahan. Bagi siswa tidak mampu menyelesaikan masalah nya, kepada mereka diberikan layanan konseling. Berbagai masukan yang ada pada diri seseorang tentang dunianya sesuai dengan 
pengalaman pribadinya dapat diungkapkan pada layanan bimbingan konseling. Masukan-masukan ini memberikan arahan secara mutlak ke arah pemenuhan kebutuhan-kebutuhan dirinya.

Guru Bimbingan dan Konseling memberikan layanan konseling kepada mereka yang secara sadar datang meminta bantuan penyelesaian masalah. Bimbingan dan konseling juga diberikan kepada mereka yang bersedia melaksanakan proses konsultasi konseling secara face to face untuk membicarakan dan memahami masalahnya, menentukan diagnosis, prognosis, dan terapinya serta evaluasi dan follow up sampai masalahnya tuntas.

Berdasarkan hasil data pelaksanaan bimbingan dan konseling Madrasah Aliyah Negeri se-Kota Banjarmasin, telah melaksanakan fungsi pengem- bangan (perseveratif) malalui layanan informasi, layanan penyaluran dan penempatan, layanan bimbingan belajar, layanan kosultasi, dan pemberian nasehat kepada siswa. Kegiatan tersebut dapat memberikan pemahaman terhadap diri pribadi siswa sangat diperlukan guna mengetahui kebiasaan baik dan buruk (Bhakti dan Safitri, 2017). Sifat baik dan buruk, kekuatan dan kelemahannya, serta potensi lingkungan berupa kesempatan dan tantangan yang harus dihadapi diberikan pada layanan bimbingan konseling Madrasah Aliyah Negeri se-Kota Banjarmasin.

Pemahaman terhadap diri pribadi siswa merupakan titik awal bagi pengembangan diri siswa (Bhakti, 2015). Dengan adanya pemahaman terhadap siswa memungkin kan guru bimbingan dan koseling bersama para siswa dapat menentukan arah pengembangan sesuai bakat dan minatnya. Disamping itu pula dengan pemberian informasi guru bimbingan konseling Madrasah Aliyah Negeri se-Kota Banjarmasin yang cukup dapat membuka peluang dan kesempatan bagi siswa dalam membuat keputusan atau pilihan pengembangan dirinya dan pemberian pemahaman kepada siswa tentang berbagai hal yang diperlukan.

Dengan terbukanya akses informasi tentang potensi diri, sosial, belajar, pergaulan, karier, pendidikan lanjutan. Maka akan membantu siswa dapat mengambil keputusan secara tepat tentang arah pengembangan diri dalam bidang pribadi, sosial, belajar maupun karier. Dari infomasi informasi yang diberikan tersebut, para siswa diharapkan lebih terbuka wawasan dan pandangan mereka, yang memungkinkan mereka lebih dinamis dan mandiri dalam upaya pengembangan kehidupan mereka (Mahdi, 2019). Pemberian informasi merupakan penerapan fungsi bimbingan dalam memberikan pemahaman dan pengembangan kepada individu-individu yang berkepen- tingan tentang berbagai hal yang diperlukan untuk menjalani suatu tugas atau kegiatan, atau untuk menentukan arah suatu tujuan atau rencana yang dikehendaki (Romlah, 2018).

Program bimbingan konseling pada Madrasah Aliyah Negeri se-Kota Bnajarmasin juga membantu siswa dalam mengenali lingkungannya. Hal ini bisa dilihat pada gambar dua dan gambar empat dimana siswa menjadi kenal dengan masalahnya dan mampu memecahkan maslah ketika masalah itu datang kembali. Yang paling terpenting dalam pelaksanaan bimbingan konseling adalah mengajarkan siswa untuk tidak lari dari masalah (Bhakti, 2015). Masalah-masalah yang dihadapi siswa dapat menjadi momen untuk dimanfaatkan sebagai pengembangan diri siswa baik untuk masa kini maupun masa yang akan datang.

Program bimbingan konseling yang tidak memberikan layanan pemberian informasi akan menghalangi siswa untuk berkembang lebih jauh (Romlah, 2018). Maka pada pelaksanaan bimbingan 
konseling Madrasah Aliyah Negeri se-Kota Banjarmasin memberikan kesempatan untuk mempelajari data dan fakta yang dapat mempengaruhi jalan hidupnya. Selanjutnya bimbingan dan konseling pada Madrasah Aliyah Negeri se-Kota Banjarmasin, telah merealisasikan fungsi pengembangan melalui layanan penempatan dan penyaluran, dengan memberikan penempatan pada jurusan, pemilihan kegiatan ekstra kurikuler, pemilihan sekolah lanjutan, dan penempatan pada layanan kerja. Layanan ini dilaksanakan untuk menghindari ketidaksesuaian antara bakat dan usaha pengembangan yang dilakukan. Dalam hal ini guru bimbingan dan konseling berusaha membantu siswa mengembangkan dan menyalurkan sesuai bakat, minat, dan potensi yang dimiliki secara tepat.

Kemudian dalam mengembangkan prestasi akademik pada Madrasah Aliyah Negeri se-Kota Banjarmasin dilaksanakan bimbingan belajar oleh guru Bimbingan dan Konseling. Bimbingan ini diberikan dengan memberikan layanan yang memungkinkan siswa mengembangkan diri berkenaan dengan sikap dan kebiasaan belajar yang baik, cara belajar yang baik, materi belajar yang cocok dengan kecepatan dan kesulitan belajarnya. Hal ini bisa dilihat pada gambar empat. Bimbingan konseling pada Madrasah Aliyah Negeri se-Kota Banjarmasin mampu menjembatani siswa dalam kegiatan belajar sesuai dengan perkembangan ilmu, dan teknologi.

Layanan bimbingan belajar adalah layanan yang diberikan oleh guru bimbingan dan konseling agar siswa dapat mengembangkan dan menyelesaikan masalah dirinya berkenaan dengan sikap dan kebiasaan belajar. Hal ini diberikan pada setiap kelas, khususnya bagi kelas $\mathrm{x}$ yang baru masuk. Mereka mengalami masa transisi dari sekolah lama kepada madrasah yang baru, yang memungkinkan adanya kesenjangan dalam kebiasaan belajar, untuk itu diperlukan layanan yang memungkin- kan peserta didik mengembangkan diri berkenaan dengan sikap dan kebiasaan belajar yang baik, cara belajar yang baik, materi belajar yang cocok dengan kecepatan dan kesulitan belajarnya. Demikian juga bagi kelas xii yang dituntut belajar lebih banyak dalam rangka persiapan menghadapi ujian nasional, mereka memerlu kan bimbingan dalam mempersiapkan ujian tersebut. Pendekatan ini terintegrasi dengan proses pendidikan di Madrasah secara keseluruhan dalam upaya membantu para siswa agar dapat mengembangkan atau mewujudkan potensi dirinya secara penuh, baik menyangkut aspek pribadi, sosial, belajar, maupun karir.

Implementasi bimbingan dan konseling di Madrasah diorientasikan kepada upaya memfasilitasi perkembangan potensi siswa, yang meliputi aspek pribadi, sosial, belajar, dan karir; atau terkait dengan pengembangan pribadi siswa sebagai makhluk yang berdimensi biologis, psikis, sosial, dan spiritual(Putra, 2015). Implikasi peranan Bimbingan Konseling di madrasahmadrasah itu sendiri adalah untuk membantu berhasilnya program pendidikan pada umumnya, membantu keberlangsungan pelaksanaan kegiatan belajar-mengajar lebih baik dan berhasil.

\section{SIMPULAN}

Dari temuan hasil penelitian dan pembahasan dapat disimpulkan bahwa :

a. Bimbingan dan konseling pada Madrasah Aliyah Negeri se-Kota Banjarmasin telah berperan aktif dalam melakukan fungsi preventif, fungsi kuratif atau korektif dan fungsi perseveratif. 
b. Bimbingan dan konseling pada Madrasah Aliyah Negeri se-Kota Banjarmasin telah berperan aktif dalam membantu siswa memecahkan masalah yang dihadapai dengan melakukan pencegahan, penyembuhan atau perbaikan, dan pengembangan terhadap para siswa madrasah, sehingga mereka selalu berada dalam kondisi stabil untuk mengikuti proses belajar di madrasah.

\section{DAFTAR PUSTAKA}

Arifin, M. (2003). Teori-teori konseling agama dan ilmu. Golden Tryon Press.

Bhakti, C, P., \& Safitri, N. E. (2017). Peran Bimbingan dan Konseling untuk Menghadapi Generasi Z dalam Perspektif Bimbingan dan Konseling Perkembangan. Jurnal Konseling GUSJIGANG, 3(1), 104-113.

Farihah, I. (2013). Peran Bimbingan Konseling Islam dalam Membangun Keberagamaan Anak Jalanan. Konseling Religi: Jurnal Bimbingan Konseling Islam, 4(1), 145-163.

Legowo, E. (2017). Model Pembelajaran Berbasis Penstimulasian Multiple Intelligences Siswa. Jurnal Kajian Bimbingan Dan Konseling, 2(1), 1-8. https://doi.org/10.17977/um001v2i1201 7p001

Lusiyana, A \& Rohman, F. (2018). Peran Bimbingan Konseling Berbasis Tiga Pilar (Guru, Orang Tua, dan Lingkungan Masyarakat) dalam Pembentukan Akhlakhul Karimah Siswa di MA Nurul Huda Kabupaten OKU Timur. Jurnal Bimbingan Dan Konseling, 3(2), 69-77.

Mahdi. (2017). Peran Guru Bimbingan dan Konseling dalam Meningkatkan Kesuksesan Belajar Siswa di Sma Negeri 1 Depok Sleman Yogyakarta.
Jurnal Edukasi: Jurnal Bimbingan Konseling, 3(1), 1-15.

Marfija, S., \& Saadah. (2018). Pengembangan Pendidikan Karakter Melalui Pelayanan BK di Sekolah. Satya Widya, 34(1), 22-30.

Muslihati. (2019). Peran Bimbingan dan Konseling dalam Penguatan Pendidikan Karakter di Sekolah Menengah Kejuruan. Jurnal Kajian Bimbingan Dan Konseling, 4(3), 101. https://doi.org/DOI:

10.17977/um001v4i32019p101

Nurhayati, N. S. N. P. (2018). Optimalisasi Peran dan Fungsi Guru Bimbigan dan Konseling Dalam Implementasi Kurikulum 13. Jurnal Bikotetik, 2(2), 147-154.

https://doi.org/http://dx.doi.org/10.276 40/bikotetik.v2n2.p147-154

Permana, S. A. (2020). Peran Guru BK dalam Meningkatkan Keterampilan Belajar dan Motivasi Belajar Siswa. Syifaul Qulub: Jurnal Bimbingan dan Konseling Islam,1(2), 61-69. https://doi.org/10.32505/syifaulqulub. v1i2.2425

Putra, A. R. B. (2015). Peran Guru Bimbingan dan Konseling dalam Mengatasi Kecenderungan Perilaku Agresif Peserta Didik di SMKN 2 Palangka Raya Tahun Pelajaran 2014/2015. Jurnal Konseling GUSJIGANG, 1(2), 12-18.

Ramlah. (2018). Pentingnya Layanan Bimbingan Konseling Bagi Peserta Didik. JURNAL AL-MAU'IZHAH, 1(1), 70-76.

Sugiyono. (2018). Metode Penelitian Kuantitatif, Kualitatif dan R \& D (28th ed.). Alfabeta. 